\title{
Social and Environmental Disclosure Rating in the Libyan Oil and Gas Sector
}

\author{
Ali Aldrugi \\ Lecturer in Faculty of Economics and Commerce at AlMergeb University- Libya \\ E-mail: amaldrugi@elmergib.edu.ly \\ Hafez Abdo \\ Senior Lecturer in Accounting at the Nottingham Business School-UK \\ E-mail: hafez.abdo@ntu.ac.uk
}

Abstract- Over the last two decades, as companies have become more responsive to investors' concerns about the environment and corporate social responsibility (CSR), they have started to provide information about the environmental and social impacts of their activities in their annual reports. The purpose of this study is to explore the practices of environmental disclosure (ED) and the extent of response of companies in Libya's oil industry to these concerns. In addition, the study aims to identify what motivates companies to disclose social and environmental information. To fulfil these aims, data was collected by means of interviews with managers and accountants from oil and gas companies operating in Libya. The findings reveal that the managers and accountants of local and foreign oil and gas companies operating in Libya are aware of and understand the significance of CSR and ED. The study found that the majority of these companies disclose some environmental information in their annual reports or at least have policies to disclose this information in the near future. They disclose three types of environmental information: good, neutral and bad news. The interviewees emphasised the benefits companies gain from corporate disclosure, such as improving the company's reputation, meeting environmental regulations and satisfying organisations interested in environmental performance. Some also suggested that companies disclose environmental information for economic reasons. On the other hand, the investigation highlighted that the most important obstacle to ED is the lack of environmental regulations and ED standards; in other words, there is no legal obligation for companies to disclose environmental information.

Index Terms: Disclosure, Environmental, Gas, Libya, Oil

\section{Introduction}

ince 1990, interest in ED has grown, and it is now seen as one of the main types of social
disclosure ${ }^{1}$. This attention has not come out of the blue; as environmental costs rise year on
year, it has become increasingly important to disclose these costs, as they can significantly impact upon the decisions made by users of companies' annual reports and accounts. Disclosure is all the more important in light of the fierce competition between companies, particularly those trading shares on the stock market. As investors have started to press for the disclosure of 
environmental information in published annual reports or in the notes accompanying these reports $^{2}$, companies have begun to respond by including some ED and CSR information.

The disclosure of environmental information indicates two key things: it shows whether companies are aware of their impact on the environment, and it represents a criterion by which stakeholders may judge the extent and magnitude of this impact, its financial implications and the efforts companies are making to minimise it ${ }^{3,4}$. Environmental costs and obligations now account for a sizeable proportion of total corporate costs ${ }^{3}$; hence, the majority of information about environmental performance is financial and quantitative in nature, reflecting the fact that this performance can have a direct impact on the financial performance of the company ${ }^{5}$. The scale of these costs and obligations is evident in the Environmental Protection Agency's estimate that almost 750 billion dollars were spent in the USA in 1991 cleaning up industrial waste disposal sites at an average cost of 25 million dollars per site. In the UK, environmental costs in that year were estimated at 14 billion pounds ${ }^{6}$. Thus, if companies are to portray their financial situation accurately, their annual reports or financial statements should reflect the actual and potential costs (including environmental costs) of any lapse in adherence to environmental protection laws ${ }^{7}$.

Despite the growing interest being shown in ED in developed countries such as the USA and the $\mathrm{UK}^{8}$, it is much rarer elsewhere; a number of studies have shown that many developing countries do not show any interest in $\mathrm{ED}^{9,10,11,12,13,14,15,16}$. The main incentive for conducting this study is to address gaps in the literature regarding CSR in general and ED in particular. Specifically, it seeks to explore the extent of response of companies in Libya's oil industry to these concerns and to identify the reasons why companies disclose social and environmental information and the obstacles that prevent them.

\section{Literature Review}

The social role of organisations has been a contentious topic in the scientific and academic communities for more than thirty years, and there is still no clear consensus among researchers on how CSR should be defined, in determining the activities and types of social responsibility and what motivates companies to disclose environmental information. Three perspectives have emerged on the issue. The first regards businesses and economic units simply as places for maximising profit ${ }^{17}$. The second holds that organisations, besides being economic actors, are also social units which should play a social role in their environment ${ }^{18,19}$. The third perspective seeks to balance the objectives of maximising profit and behaving in a socially responsible way. Proponents of this perspective claim that companies can simultaneously maximise performance and meet the social obligations that are imposed on them by law without compromising their ability to compete and develop $20,21,22$.

The lack of a universally agreed definition of CSR Leads to a difference of opinions regarding the activities and types of responsibility it involves. Five broad areas or groups of activities have been identified so far. These are: activities relating to natural resources and environmental contributions (environment protection); activities relating to human resources (staff); activities 
relating to public contributions (society); activities in the energy field (energy saving); and activities relating to products or services (consumer protection) (American Accounting Association ${ }^{9,23,24}$. Other studies have focused on identifying the reasons why companies undertake ED and the obstacles that stop them from disclosing environmental information. The general consensus is that companies disclose environmental information primarily to improve their image and reputation $25,26,27,28,29,30,31$, but controversy still exists as to the influence of other factors such as societal expectation, legal requirements, social pressure and economic factors ${ }^{32,33,34,35}$. On the other hand, according to ${ }^{14}$, corporate social responsibility disclosure (CSRD) is inhibited by: "barriers related to lack of resources, followed by barriers related to the complexity and difficulty of implementing CSRD and finally, lack of management support at both top and middle levels".

Four major studies have focused specifically on CSRD and ED in Libya. Mashat ${ }^{36}$ and Elmogla ${ }^{37}$ aimed to identify the influence of external social, political and economic factors on CSRD. The main objective of Mashat's study was to investigate CSRD practice across four Libyan business sectors (manufacturing, banks, insurance and other services such as external auditors) and how it was affected by the country's social, political and economic environment in the period 1999 to 2002. The results indicated that most companies provided some measure of social disclosure, although the volume of information disseminated was low compared to their counterparts in developed countries. Mashat argued that social, political and economic factors have an impact on CSRD and confirmed that possible reasons for non-disclosure include the lack of mandatory disclosure requirements, the weakness of the accounting profession in Libya, and a lack of awareness of the importance and potential benefits of CSR disclosure.

In a similar vein, Elmogla's study investigated CSRD in Libyan companies' annual reports and how it was impacted by the economic, social and political environment between 2001 and 2005. Elmogla's sample included industrial companies, financial service enterprises (banks and insurance companies) and other service companies such as external auditors, and featured both private and government-controlled organisations. Like Mashat, he found that Libyan companies generally disclose some information related to social responsibility, but that the amount of information is low compared with companies in developed countries. Employee and community involvement are the main themes in their disclosure, and companies prefer to place social information in the annual report, ideally in a separate section. Companies in the study accepted the need to disclose more social and environmental information and saw disclosure as yielding socioeconomic benefits at the macro level. Although these studies investigated the influence of external factors on CSRD in general, neither one made any specific reference to ED; both authors suggest that further research is required into the disclosure of social information, particularly environmental information, in the Libyan context.

The two studies that focus primarily on ED in Libya took different approaches from the present study. Saleh ${ }^{38}$ studied the extent to which ED occurs in Libya, identifying how administrative decisions regarding ED were influenced by (but did not influence) the social, political and economic situation between 1998 and 2001 (i.e. more than ten years ago). His study was carried 
out on 13 local industrial companies. The results indicated that the social context, including religion, influenced ED practice to some extent, but that the main determinants were the country's unique political and economic context, and manager attitudes and qualifications. The findings reflect the influence external (political, economic and social) factors can have on the disclosure environment.

A second study, by Ishwerf ${ }^{39}$, investigated stakeholders' perceptions and requirements of ED in the Ahlia Cement Company, a local company. Adopting the case study approach, Ishwerf's sample included six stakeholder groups: regulators and policy makers, local government, shareholders, managers, employees and financial institutions. The results showed that stakeholders ranked environmental information as the highest disclosure priority, though they ranked environmental financial issues and energy issues last and second to last respectively. The results imply that regulators and policy makers, as well as companies themselves, should consider the policy implications of other stakeholders' views.

To sum up, although a number of studies have been conducted in the field of CSR and ED, addressing a range of issues from how to define the concept of CSR and the types of activities associated with it, to the level of ED in different countries, the majority of ED-related studies have focused solely on developed countries. However, many authors agree that it may be misleading to apply the results of western studies to other countries, since economic, social, political and cultural differences mean that ED varies from one country to another and even from one community to another $40,41,42,43$.

Moreover, the studies that have been conducted in the Libyan context focus on local industrial companies operating outside the oil and gas sector. In contrast, the present study focuses exclusively on this sector, which is generally considered the most polluting industrial sector ${ }^{44}$. This is also Libya's most important industry in economic terms, accounting for $70 \%$ of GDP and $98 \%$ of exports ${ }^{45}$. Rather than limiting the focus to local companies, as previous studies have done, the present study examines the activities and attitudes of both local and foreign companies operating in the sector. In its attempt to clarify the determinants of ED, it assesses whether the reasons that have been advanced as motives for ED do in fact drive ED, and identifies those obstacles that prevent companies from disclosing environmental information.

A further consideration is that three out of the four Libya-based studies discussed above rely on data covering a three or four year period somewhere between 1999 and 2005 since Ishwerf's study used case study. For most of this period, Libya was under siege; the UN Security Council, supported by the USA and the UK, imposed sanctions on Libya and froze Libyan financial assets in 1992, suspending the sanctions in 1999 and finally lifting them in full in September 2003. The sanctions meant there was little interest in training courses outside the oil industry (which has historically been assiduous about training) as most industrial companies were suffering acute financial hardship. It was not until 2003 and the lifting of the sanctions that Libya's environment 
economic began to improve. One of the main drivers behind the study, therefore, is to update the literature on this topic.

Thus, the fundamental questions guiding this study are:

Is there understanding of CSR in general and ED in particular in Libyan oil and gas companies?

What is the importance of social and environmental disclose to the companies?

Do oil companies operating in Libya practise ED? If so, what type of environmental information is being disclosed?

What motivates companies to disclose their environmental activities?

What factors prevent companies from disclosing their environmental information?

\section{Methodology}

To answer the research questions and achieve its aims, which are exploratory and explanatory in nature, interviews were selected as the main data collection method. These were conducted by the authors in January and February 2011 with managers and accountants working in local and foreign oil and gas companies operating in Libya. The study population was made up of 43 oil companies, 13 of which are national companies, with the remaining 30 being affiliated to foreign companies. However, the authors experienced major difficulties when trying to secure interviews with representatives. Several managers rejected the invitation to be interviewed under the pretext of having a busy schedule, with the result that in the end, the authors were only able to conduct 10 interviews. These interviews were only granted after respondents had been promised that their names would not be disclosed and that they would be identified in the research by numbers or letters only. The table below shows the number of interviews that were eventually conducted in foreign and local companies. It should be noted here that this study represents a continuation of previous research by the same authors $46,47,48$.

Interviews Conducted in Local and Foreign Companies

\begin{tabular}{|l|c|c|c|c|c||c|c|c|c|}
\hline & \multicolumn{5}{|c||}{ Local companies } & \multicolumn{3}{c|}{ Foreign companies } & Total \\
\hline Companies & $\mathrm{A}$ & $\mathrm{B}$ & $\mathrm{C}$ & $\mathrm{D}$ & $\mathrm{E}$ & $\mathrm{F}$ & $\mathrm{G}$ & $\mathrm{H}$ & \\
\hline $\begin{array}{l}\text { Number of } \\
\text { managers }\end{array}$ & 1 & 0 & 0 & 1 & 0 & 1 & 0 & 0 & 3 \\
\hline $\begin{array}{l}\text { Number of } \\
\text { employees }\end{array}$ & 1 & 1 & 1 & 0 & 1 & 1 & 1 & 1 & 7 \\
\hline Total of interviews & 2 & 1 & 1 & 1 & 1 & 2 & 1 & 1 & 10 \\
\hline
\end{tabular}

\section{Data Discussion and Analysis}


The rest of this paper will be allocated to the analysis and discussion of the data which was collected from the interviews with managers and accountants in local and foreign oil and gas companies operating in Libya. Managers will be indicated by the number 1 and accountants by the number 2 in the analysis to make discrimination between the two groups easy.

\section{4-1- Understanding of CSR and ED}

The main purpose of this section is to understand the perceptions and views of participants regarding CSR and ED. It attempts to establish the extent to which the concept of CSR and the importance of ED are recognised and understood by managers and accountants working for oil and gas companies in Libya. To this end, the interviewees were asked the following question: From your point of view, what do CSR and corporate ED mean?

Interestingly, the interviewees defined CSR in different ways. However, their definitions all show clear understanding of the concept.

F1 defined CSR as:

...the commitment of companies to take account of the requirements of society that take into consideration the expectations of society as a concern of employees and environment and it goes beyond the economic and legal requirements. In addition, CSR should be a high priority within the company; concern for CSR should be balanced with the economic interests of the company.

H2 said:

I think CSR is voluntary and compulsory: corporate behaviours towards society that aim to achieve social welfare in the various social fields. For instance, the company can play an active part by allocating some of its profits to protect the environment from pollution. This can also be shown in developing and promoting health education programmes for staff and their families in particular and society in general. So companies should consider their social and environmental responsibility in equal proportion to their economic interests; at least, they should abide by the requirements of the law.

In this connection, A1 indicated:

CSR is the commitment to reduce the adverse effects of the company's activities and to contribute to solving social problems. For example, companies should aim at tackling corruption and protecting the environment. So it should go beyond the mandatory work to include voluntary actions, though only in so far as it is in line with the interests of the shareholders.

The above definitions show that these respondents all believed that CSR involves companies going beyond their legal and economic obligations and seeking to limit the negative impacts of their activities and find solutions to the many problems of society, but without affecting 
shareholders' and owners' interests in the process. All but one interviewee saw CSR as being essentially voluntary in that it involves going over and above legal requirements; only C2 disagreed, arguing that companies exhibit CSR simply by conforming to the laws and social regulations set by the government. In other words, CSR is a mandatory responsibility, not a voluntary gesture. He explained:

In my view CSR is how companies manage their business to fully meet their social responsibility which is required by law.

The respondents' answers indicate that managers and accountants working in local and foreign oil and gas companies operating in Libya are aware of and understand the core meaning and functions of CSR.

On a similar line of enquiry, participants were asked to explain their understanding of ED. Almost all of the interviewees gave similar answers. They claimed that ED is one of the major components of social disclosure and that it involves the disclosure of environmental information in annual reports or in special reports. It may be voluntary or compulsory, depending on the prevailing laws or environmental regulations. G2 explained:

ED is one of the most important types of social disclosure related to environmental activities, and it may be voluntary or mandatory. It gives users environmental information, which helps them to make their investment decisions and evaluate organisations.

One can therefore conclude that managers and accountants working in local and foreign oil and gas companies operating in Libya are aware of and understand both CSR and ED.

Although the majority of respondents who participated in the study were highly educated and there is increasing emphasis on reporting environmental practices, this result is surprising because it is not consistent with those of prior studies. For example, Mashat ${ }^{36}$ believed that one possible reason for the low level of social disclosure in Libyan companies compared to their counterparts in developed countries was a lack of awareness of both the importance of CSR disclosure and its potential benefits. This result also disagrees with $\mathrm{Saleh}^{38}$, who indicated that Libyan managers are ill-equipped to handle environmental issues and therefore have poor awareness and understanding of ED. He ascribed his finding to the fact that none of the managers in his study had taken part in any training courses or programmes to improve their knowledge about environmental management and/or accounting. There are several possible explanations for why this study's findings differ from Saleh's. Most significantly, Saleh's study, though undeniably important, was conducted using a sample of just 13 industrial companies, none of which were in the oil sector. Furthermore, the study was conducted between 1998 and 2001 - more than ten years ago. 


\section{4-2- The Importance of CSR and ED}

This section provides the empirical results relating to the participants' views on the importance of including CSR and ED in annual reports. In order to establish what these views were, the interviewees were asked the following questions: From your point of view, why should companies pay attention to CSR and ED (or why shouldn't they)?

Many participants pointed out that CSR and ED can have a double return. As much as they are for the benefit of the community, they are also of extreme advantage to the company. D1 made the following comment:

Yes, companies receive several advantages by carrying out their CSR and ED. CSR and ED result in positive effects that will accrue various benefits for companies in the short term as well as in the long term. For example, increased volume of activity, expansion in the investment sector, building and enhancing a positive public image for the company, the achievement of some competitive benefits and protection from certain legal risks.

In this connection, F2 demonstrated a good understanding of the benefits of CSR and ED when he said:

CSR and ED are important for increasing the company's transparency, raising the value of the company's shares and protection of companies from certain legal risks. In addition, they help companies to improve their image and reputation before the public. However, in order for a company to receive the maximum benefit of CSR and ED, there should be legal legislation, standards and accounting rules that organise the carrying out of companies to the CSR and ED.

At first glance, a limited approach to CSR and ED may appear to have a negative impact on the economic performance of companies as they may increase costs and reduce profits in the short term. However, the authors believe that a careful and comprehensive view of corporate environmental performance and disclosure will show the opposite.

The results above support our argument and confirm that CSR and ED have many advantages, whether in the short or long term. It was not surprising then that the idea that an organisation's sole responsibility is to maximise profits was strongly rejected by almost all interviewees. Only one interviewee (E2) saw no point in voluntary CSR or disclosing environmental information where this is not legally required; in fact, he regarded these as costly activities that bring no benefits to the disclosing corporation:

There are no significant advantages of CSR and ED that justify exposing companies to many risks and bearing unnecessary costs. Especially in light of the absence of legal legislation, standards and accounting rules that require and oblige companies to carry out CSR and disclose their environmental information. In my opinion, CSR and ED 
are a waste of time, effort and money. They have no real benefit for companies compared with their cost.

In summary, it can be said that the managers and accountants interviewed here were fully aware of the importance and necessity of CSR and ED and understood these concepts. Although some interviewees felt that the costs of CSR and ED may outweigh their benefits, only one interviewee did not see the significant advantages to be gained from CSR and ED. Arguing that that these activities may lead to increased costs and reduced profits in return, this interviewee saw CSR and ED as a waste of resources that could be better used elsewhere.

\section{4-3- ED Quantity and Types}

One of the main objectives of this study is to identify the type of environmental information that appears in the annual reports of local and foreign oil and gas companies operating in Libya. In order to meet this objective, the following questions were put to the interviewees:

1. Does your company disclose any environmental information in the annual reports?

2. If the answer to the above question is yes, what type of news is disclosed?

3. If the answer to question 1 is no, does your company have an environmental policy?

4. If the answer to question 3 is yes, why does your company not disclose this policy?

5. If the answer to question 3 is no, does the company intend to establish an environmental policy in the near future?

The majority of interviewees confirmed that their companies disclose some environmental information in their annual reports, though more attention is given to good news than to news that is bad or neutral. For example, D1 indicated that:

As a result of the benefits of ED our company has started to disclose some environmental information in its annual reports since 2002. It is still interested in good news more than bad news. Although in the beginning it focused on the good, now it reports some bad and neutral news.

H2 believed that:

Society is not interested in environmental information, but this may be because they are not aware of the importance and the necessity of this information. Also there are no Libyan legal requirements that oblige companies to disclose their environmental information. Our company's interested in voluntary disclosure and it discloses social and environmental information of all three types: good, bad and neutral. But to be honest, good news is given more interest than other types of ED.

The interviewees' responses suggest that they viewed disclosing ED and CSR information as fashionable; it is an important practice because it improves the reputation and image of 
companies and hence their performance. However, more attention was paid to the disclosure of good news in both local and foreign companies.

On the other hand E2 claimed that:

Our company is not interested in environmental and social disclosure at the moment although it carries out many social and environmental activities, and this is because the environmental costs are already included in the industrial expenses and it is difficult to separate them. In addition, there are no environmental laws, standards or accounting rules that require companies to disclose environmental information. Also, society is not interested in environmental and social information. Hence, companies prefer to charge the costs of protecting the environment to production costs.

When this interviewee was asked whether his company has an environmental policy, he reported:

Yes, our company has many social and environmental activities and it is starting to set environmental policies which will be applied in the future to meet some of the environmental laws and regulations issued recently. Although in practice there is no total or real obligation, these policies will be disclosed in the near future.

The findings indicate that although the companies in the sample gave numerous reasons for not disclosing information about their social and environmental activities, most disclosed at least some of this information. The vast majority disclosed some environmental information in their annual reports, or at least had policies to do so in the near future. However, there was a general agreement that, although there is some disclosure of bad and neutral news, the vast majority of this disclosure focuses on good news.

The main reason given by interviewees for companies not implementing an ED policy was the lack of legal requirements, standards and accounting rules obliging companies to disclose information about their environmental activities. The belief that society is not very interested in environmental and social information may be another reason why companies do not bother to disclose this information.

\section{4-4- Reasons for Disclosure of Environmental Information}

The objective of this section is to identify the reasons why companies disclose environmental information. In order to meet this objective, the managers and accountants working in oil and gas companies operating in Libya were asked the following question: From your point of view, do you see any real reasons for engaging in corporate ED?

The responses to this question reveal that there are many reasons why companies disclose environmental information. Primarily, ED is seen as bringing several advantages to companies. Most importantly, it helps companies to improve their reputation and fosters goodwill with the public. This is especially valuable for foreign companies, who are usually regarded with suspicion 
by local populations convinced they have come to steal the wealth of their country. In addition, (ED) gives an impression of the extent of the company's commitment to environmental laws and meets the pressure from organisations interested in the environmental performance and pressure groups as a whole

Ultimately, this improvement in reputation is expected to translate into improved financial performance, as G2 explained:

The main reason for disclosing environmental information is to increase revenues, because the value of shares in the capital market tends to be higher with ED. So by carrying out ED, the company builds a sense of confidence among its clientele, which helps to increase the number of investors.

Ascribing the growing interest in ED to the arrival of foreign companies in Libya, A1 suggested that many local companies have implemented environmental disclosure as a way of keeping up with their foreign competitors:

The concern with ED in oil and gas companies in Libya increased after the arrival of foreign companies in 2005. Many local companies are trying to follow or to catch up with foreign companies regarding disclosure of environmental information in their annual reports or in other reports. In my opinion, it has become fashionable and meets new environmental regulations to disclose some environmental information. I am sure that companies will get some benefits from ED; at least it will put local companies in the right way to compete with foreign companies, although the current disclosure is not enough and not available for the general public.

Engaging in ED also shows stakeholders that the company is committed to following environmental laws. It is a way of meeting the expectations of pressure groups and other organisations interested in environmental performance. F2 explained that:

ED helps the company to meet the environmental regulations and pressure from users, organisations interested in environmental performance and pressure groups as a whole. I believe that there is no good and adequate ED without pressure from the community and pressure groups, especially in the absence of environmental regulations and laws obliging companies to disclose environmental information in their reports.

In their responses, the interviewees laid great emphasis on the benefits companies can obtain by implementing ED, such as improving the company's reputation, meeting environmental regulations and satisfying environmental organisations and pressure groups. These benefits were seen as the major reasons for implementing ED, but the potential economic benefits were also mentioned as another motive that encourages companies to disclose environmental information. The local companies did not consider competition to be a significant factor in the introduction of $\mathrm{ED}$, but the comment made by one of the interviewees, that it was the entry of foreign companies into the Libyan oil sector that triggered the interest in ED, suggests that competition is starting to 
play a key role in determining the level and type of ED oil companies - both local and foreign implement in Libya. This is a new motivation that has not been touched upon in previous studies. This is surprising, given that competition between local and foreign oil companies has only developed since arrival many new foreign companies in 2005

\section{4-5- Obstacles that Might Prevent Companies Disclosing Environmental Information}

One of the important aims in this research is to identify the obstacles that might stop companies disclosing environmental information. Accordingly, the participants were asked the following question: In your view, what are the key reasons that might prevent companies from disclosing environmental information?

A number of obstacles were identified by the interviewees, from the lack of a mandatory requirement to a lack of concern by shareholders. $\mathrm{H} 2$ pointed out that:

The absence or lack of environmental laws is the main reason that prevents companies disclosing environmental information. Also there are no financial or moral incentives for companies to disclose environmental information.

D1, meanwhile, pointed out that the potential benefits of ED in terms of improving reputation are less important to publicly owned companies:

I think the main reason for corporate ED is to enhance companies' image and reputation in the eyes of stockholders and new investors. Local oil and gas companies in Libya are public companies and they do not have shareholders or shares in their stock traded on the market. Thus, they are not too concerned to improve their image and reputation. In addition, there seems to be no demand by the users of annual reports for environmental information and no attention is paid to such information. Thus, local companies are incurious about ED, especially as it is still voluntary rather than mandatory. Moreover, many companies may believe that the cost of disclosing environmental information outweighs its benefits; therefore, some companies are unenthusiastic about disclosing environmental information.

A number of other interviewees also argued that there are multiple barriers stopping companies from disclosing environmental information. One of the most important obstacles is the lack of environmental regulations and ED standards to guide companies in the disclosure of environmental information; many companies want to engage in ED but find it difficult to know how in the absence of regulations and standards. Such regulations and standards can help companies to overcome problems and avoid confusion, for example where there is an overlap between industrial costs and environmental costs (some people may think mistakenly that they add up together in the cost of the final product).

To sum up, the comments of the interviewees suggest that there are several barriers that may stop companies from disclosing environmental information. The majority of interviewees agreed that one of the most important obstacles is the lack of any real legal obligation for companies to 
disclose environmental information. For those companies that choose to implement ED, the lack of environmental regulations and ED standards makes the process more difficult. Many participants also pointed out that there are no financial or moral incentives that might encourage companies to disclose environmental information. For example, the state could offer tax incentives or give disclosing companies priority in terms of new contracts for future oil exploration. The overall combination of a lack of serious penalties and rewards to motivate companies on the one hand, and obstacles hindering disclosure on the other, means that many companies pay little attention to ED. Furthermore, as the local oil companies are all public entities, they were perceived by some participants as having little use for ED; these interviewees argued that in these companies, this type of information is not required either by the users of the annual reports or by society as a whole. Finally, some interviewees expressed the belief that the costs of providing this type of information may far exceed the desired outcomes. The findings thus indicate that although oil companies in Libya seem to be well aware of what ED is and the benefits it can bring, its development and widespread implementation have been hindered by a number of obstacles.

\section{Conclusion}

The purpose of this study is to explore the practice of ED and the extent of response of companies in Libya's oil industry to their investors' environmental concerns. It also seeks to identify the perceived importance of ED and the reasons why companies disclose environmental information. To achieve these objectives, the authors used interviews to gain an insight into the attitudes of managers and accountants in oil and gas companies operating in Libya.

Although the participants were not satisfied with the current environmental laws and ED standards, or the lack of either reward or punishment, the results give conclusive evidence that managers and accountants in oil and gas companies operating in Libya understand the concepts of CSR and ED and see the necessity of ED. The majority of companies disclosed some environmental information in their annual reports or at least had policies to disclose this information in the near future. There was a general agreement that there is some disclosure of bad and neutral news, but that the vast majority of disclosure focuses on the good news. The interviewees cited the benefits obtained by companies from ED as the major reasons for corporate disclosure; these benefits include improved reputation, meeting environmental regulations and satisfying environmental organisations. Interestingly, the potential economic benefits received less emphasis. The results also indicate that some local companies disclose environmental information in their annual reports in an effort to follow or catch up with foreign companies.

On the other hand, the results confirm that in the absence of a legal requirement, some companies are reluctant to engage in ED. In the absence of either punishment or reward, they have little incentive to disclose information, but even those who are willing to implement ED feel they lack the knowledge to do so. There is also a concern that the cost of disclosing this type of information may outweigh the benefits. 
As has already been pointed out, there is a shortage of research related to ED in developing countries, particularly Libya. No study has been conducted on ED in the Libyan oil and gas sector; those studies that have been conducted in the Libyan context have excluded the oil sector and foreign companies. For these reasons, the results of this research are particularly significant.

\section{Further Research}

The results of this study raise many further research possibilities; we echo other authors in calling for more research to be conducted on social and environmental disclosure in corporate reports, especially in developing countries. For example, researches might be conducted to develop environmental standards to help companies in Libya measure and assess the value of their environmental activities and disclose their environmental information effectively. It would be especially useful to conduct a similar study on a wider sample of Libyan companies, investigating their behaviour and attitudes towards ED since the 2011 revolution.

In light of the results of this study, further research is needed into the obstacles that prevent companies from disclosing environmental information. Further investigation is also required of CSRD in other areas such as human resources, product development and energy saving. 


\section{References}

1. Islam, S., Hosen, A. and Islam, M., "An Examination of Corporate Environmental Disclosure by the Bangladeshi Public Limited Companies," Journal of Social Sciences 3, no. 9 (2005): 1095-1102.

2. Deegan, C. and Rankin, M., "The Materiality of Environmental Information to Users of Annual Reports," Accounting, Auditing and Accountability Journal 10, no. 4 (1997): 562-583.

3. Cormier, D. and Magnan, M., "Environmental Reporting Management: A Continental European Perspective,' Journal of Accounting and Public Policy 22 (2003): 43-63.

4. Akhtaruddin, M., "Corporate Mandatory Disclosure Practices in Bangladesh," The International Journal of Accounting 40, no. 4 (2005): 399-422.

5. Marston, C. and Shrives, P., "The Use of Disclosure Indices in Accounting Research: A Review Article," British Accounting Review 23, no. 3 (1991): 195-210.

6. Rezaee, Z., Szendi, J. and Aggarwal, R., "Corporate Governance and Accountability for Environmental Concerns," Managerial Auditing Journal 10, no. 8 (1995): 27-33.

7. Cornell, D.and Apostolou, B., "Auditing for Violations of Environmental Laws," The National Public Accountant 37, no. 7 91991): 16-20.

8. Gamble, G., Hsu, K., Jackson, C. and Tollerson, C., "Environmental Disclosures in Annual Reports: An International Perspective," The International Journal of Accounting 31, no.3 (1996): 293-331.

9. Gao, S., Heravi, S. and Xiao, J., "Determinants of Corporate Social and Environmental Reporting in Hong Kong: A Research Note," Accounting Forum 29, no. 2 (2005): 233-242.

10. Belal, A. and Owen, D., "The Views of Corporate Managers on the Current State of, and Future Prospects for, Social Reporting in Bangladesh," Accounting, Auditing and Accountability Journal 20, no 3 (2007): 472-494.

11. Jamali, D., "The Case for Strategic Corporate Social Responsibility in Developing Countries", Business and Society Review 112, no.1 (2007): 1-27.

12. Sobhani, F., Amran, A. and Zainuddin, Y., "Revisiting the Practices of Corporate Social and Environmental Disclosure in Bangladesh," Corporate Social Responsibility and Environmental Management 16, no. 3(2009): 167-183.

13. Gugler, P. and Shi, J., "Corporate Social Responsibility for Developing Country Multinational Corporations: Lost War in Pertaining Global Competitiveness?," Journal of Business Ethics 87 (2009): 3-24.

14. Arevalo, J. and Aravind, D., "Corporate Social Responsibility Practices in India: Approach, Drivers, and Barriers," Corporate Governance 11, no. 4 (2011): 399-414.

15. Babiak, K., and Trendafilova, S., "CSR and Environmental Responsibility: Motives and Pressures to Adopt Green Management Practices," Corporate Social Responsibility and Environmental Management 18, no. 1 (2011): 11-24.

16. Belal, A. and Cooper, S., "The Absence of Corporate Social Responsibility Reporting in Bangladesh," Critical Perspectives on Accounting 22, no. 7 (2011): 654-667. 
17. Friedman, M., "'The Social Responsibility of Business is to Increase its Profits,' The New York Times Magazine 33, no. 1 (1970): 122-126.

18. Spicer, B., "Accounting for Corporate Social Performance: Some Problems and Issues," Journal of Contemporary Business, winter (1978): 151-167.

19. World Business Council for Sustainable Development. "Corporate Social Responsibility" the WBCSD's Journey, Accessed June 01, 2011, http://www.wbcsd ch/DocRoot/IONYLirijYoHBDflunP5/csr2002 pdf

20. European Commission, "Green Paper: Promoting a European Framework for Corporate Social Responsibility,' COM, Brussels 366 (2001):1-32.

21. Mcwilliams, A. and Siegel, D., "Corporate Social Responsibility: A Theory of the Firm Perspective,' Academy of Management Review 26, no. 1 (2001): 117-127.

22. Turker, D., 'Measuring Corporate Social Responsibility: A Scale Development Study,' Journal of Business Ethics 85 (2009): 411-427.

23. American Accounting Association (AAA), "Committee on Social Costs", The Accounting Review 50, no. 4 (1975): 50-89.

24. Williams, M., "Voluntary Environmental and Social Accounting Disclosure Practices in the Asia-Pacific Region: An International Empirical Test of Political Economy Theory,' The International Journal of Accounting 34, no. 2 (1999): 209-238.

25. Patten, D., "Intra-Industry Environmental Disclosure in Response to the Alaskan Oil Spill: A Note on Legitimacy Theory," Accounting Organizations and Society 17, no. 5 (1995): 471475.

26. Adams, C., Hill, W. and Roberts, C., "Corporate Social Reporting Practices in Western Europe: Legitimating Corporate Behaviour,'’ British Accounting Review 30 (1998): 1-21.

27. Deegan, C., "'Introduction the Legitimising Effect of Social and Environment Discloures - A Theoretical Foundation,' Accounting, Auditing and Accountability Journal 15, no. 3 (2002): 282-311.

28. Deegan, C., Rankin, M., Tobin, J., "An Examination of the Corporate Social and Environmental Disclosure of BHP From 1983-1997 A Test of Legitimacy Theory," Accounting Auditing and Accountability Journal 15, no. 3 (2002): 312-343.

29. Gary, D., "Environmental Disclosures in the Annual Report: Extending the Applicability and Predictive Power of Legitimacy Theory,' Accounting Auditing and Accountability Journal 15, no. 3 (2002): 344-371.

30. Cho, C. and Patten, D., "The Role of Environmental Disclosures as Tools of Legitimacy: A Research Note,'” Accounting, Organizations and Society 32, no.7 (2007): 639-647.

31. Tilling, M. and Tilt, C., “The Edge of Legitimacy Voluntary Social and Environmental Reporting in Rothmans' 1956-1999 Annual Reports,' Accounting Auditing and Accountability Journal 23, no. 1(2010): 55-81.

32. Guthrie, J. and Parker, L., 'Corporate Social Reporting: A Rebuttal of Legitimacy Theory,' Accounting and Business Research 19, no. 76 (1989): 343-352. 
33. Hogner, R., "Corporate Social Reporting: Eight Decades of Development at US Steel," Research in Corporate Social Performance and Policy 4 (1982): 243-250.

34. Campbell, D., "Legitimacy Theory or Managerial Reality Construction? Corporate Social Disclosure in Marks and Spencer Plc Corporate Reports, 1969-1997', Accounting Forum 24, no. 1(2000): 80-100.

35. Ahmad, N. and Sulaiman, M., "Environmental Disclosures in Malaysian Annual Reports: A Legitimacy Theory Perspective", International Journal of Commerce and Management 14, no. 1 (2004): 44-58.

36. Mashat, A., "Corporate Social Responsibility Disclosure and Accountability" (PhD diss., Manchester Metropolitan University, 2005).

37. Elmogla, M., "Corporate Social Reporting in a Transition Economy: The Case of Libya" (PhD diss., University of Huddersfield, 2009).

38. Saleh, N., "Corporate Environmental Disclosure in Libya" (PhD diss., Napier University, 2004).

39. Ishwerf, A., "Stakeholders' Requirements and Perceptions of Corporate Environmental Disclosure in Libya" (PhD diss., University of Salford, 2012).

40. Belkaoui, A., "Economic Political and Civil Indicators and Reporting and Disclosure Adequacy," Journal of Accounting and Public Policy 2, no. 3 (1983): 207-219.

41. Adhikari, A. and Tondkar, .H., "Environmental Factors Influencing Accounting Disclosure Requirements of Global Stock Exchanges", Journal of International Financial Management and Accounting 4, no. 2 (1992): 75-105.

42. Archambault, J. and Archambault, M., "A Multinational Test of Determinants of Corporate Disclosure," The International Journal of Accounting 38, no. 2 (2003): 173-194.

43. Elnaby, H., Epps, R. and Said, A., "The Impact of Environmental Factors on Accounting Development," Critical Perspectives on Accounting 14, no. 3 (2003): 273-292.

44. Wang, H., Bi, J., “Wheeler, D., Wang, J., Cao, D., Lu, G. and Wang, Y., “ Environmental Performance Rating and Disclosure', Journal of Environmental Management 71, no. 2 (2004) 123-133.

45. Central Bank of Libya, “Annual Report, Tripoli Libya Report Number 53 (2009).

46. Abdo, H. and Aldrugi, A., "Do Companies Characteristics Play Key Roles in the Level of Their Environmental Disclosure?'” Energy Research Journal 3, no. 1(2012): 1-11.

47. Aldrugi, A. and Abdo, H., "Investigating the Development of Environmental Disclosures by Oil and Gas Companies Operating in Libya: a comparative study", The International Journal of Economics and Finance Studies 4, no. 2 (2012): 1-10.

48. Aldrugi, A. and Abdo, H., "Determining the motives or reasons that make companies disclose environmental information", Journal of Economics, Business and Management 2, no. 2 (2014): 117-121. 